\title{
Adaptation of Variety Diversity on Growth and Production in the Area of Onion Plant Marginals (Allium ascalanicum L.)
}

\author{
Ambo Upe ${ }^{1}$ and Tenri Sau ${ }^{2}$ \\ ${ }^{1}$ Agricultural Science, STIP Puangrimaggalatung, Sengkang, South Sulawesi, Indonesia. \\ Email: amboupestip1969@gmail.com \\ ${ }^{2}$ Agricultural Science, STIP Puangrimaggalatung, Sengkang, South Sulawesi, Indonesia. \\ Email: tenrisau779@gmail.com
}

\begin{abstract}
The study aims to obtain variety with broad adaptations that are able to grow and produce optimal production on marginal fields of onion planting, which can improve farmers' welfare, reduce dependence on red onion imports, become exporters of onion to food sovereignty. The method that will be used is a Randomized Block Design (RBD) method consisting of five red onion variety as treatment, namely BimaBrebes, Tajuk, Bauji, Super Philip, and Local Enrekang variety. Each treatment was repeated three times. Data processing with SPSS Software, Version 22, and if there is a real influence, then a different test is performed with the Duncan Test at the level of ap $=0.05$. The research was carried out on the experimental land of STIP PuangrimaggalatungSengkang. The parameters observed consist of the growth and production of onion plants. The results of the analysis showed that the onion variety that was quite adaptive was BimaBrebes variety onion and was able to produce an average production of $12.08 \mathrm{tha}^{-1}$.
\end{abstract}

Keywords-Adaptation, Onion, Marginal, Growth, Production.

\section{INTRODUCTION}

Wajo is one of the districts that are considered marginal to the onion crop, because farmers do not know and are not touched by the cultivation of onion. There needs to be an effort to adjust the environment of some onion varieties to the location to be cultivated by conducting adaptation tests in the form of research. According to the Census in 2011, the consumption rate of red onion in Indonesia per capita per year reached $4.56 \mathrm{~kg}$ or $0.38 \mathrm{~kg}$ per capita per month (BPS, 2015). In order to meet the needs of the growing onions hence the need for a breakthrough technology that can improve the cultivation of onion production (Rahayu et al., 2016).

Adaptation of variety in the area considered marginal to the onion crop is early idea to support the technology development and land productivity as well as a vehicle of information science and knowledge. According to Kelvin (2014), onion cultivation technology development requires dissemination to farmers, including high yielding variety with productivity. According toIndah (2016), high-yielding variety of onion expected is adaptive variety that have high productivity, harvesting early maturing, resistant to pests and diseases, able to grow in the growth environment or agroekologi and quality of tubers in accordance with the wishes of consumers. Sembrani, Tuk-Tuk, Kuning and Medan variety have been able to adapt in the lowlands. Medan variety with a production range of 6.40-7.45 tons / ha (Sinaga et al., 2013).

Asrijal et al. (2018), onion that has the ability to grow quite well is onion of Bima variety, when compared with onion of Tajukand Super Philip variety, with the average yield at 10:43 $\mathrm{t} \mathrm{ha}^{-1}$. Better production in Moujung and Sumenep variety, namely production of 6.34-8.02 $\mathrm{t} \mathrm{ha}^{-1}$. Variety that are tolerant of Fusarium wilt attacks areMoujung (attack rate is 1.84\%). while tolerant to Alternaria is Moujung and Sumenep (attack rate 9.60\% $15.86 \%$ ) (Purbiati et al., 2010) ..successful growth until onion production, Besides is affected by the potential and quality of seeds or seedlings are sourced of various types of variety, also very dependent on the potential of the environment as a place of planting, including the altitude of the place, the condition of the climate and the level of soil fertility.

According to Suryana (2008), plants grow and develop fertile if the nutrients provided can be absorbed by a plant and in the form needed for its growth. Napitupulu and Winarto (2009), nutrients that are sufficient for onions can increase the weight of tuber crops. Damanik et al. (2010), potassium is needed for the process of photosynthesis and can increase the weight of onion bulbs. Furthermore, Fatmawati et al. (2015) NPK compound fertilizer can affect the growth and yield of onion, and can provide increased yields. According 
Asrijal et al. (2018) red onions need fertile soil fertile and high in organic matter with the support of sandy clay or clay dust.

\section{MATERIALS AND METHODS}

This research was carried out on the experimental field of STIP PuangrimaggalatungSengkang. Using Randomized Block Design (RBD) consisting of five treatments of shallot varieties, namely the BimaBrebes, Tajuk, Bauji, Super Philip, and Enrekangvarieties, the treatment was repeated three times. The parameters were observed consisting of growth and production of red onion. Processing data with SPSS Software, Version 22, and if there is a real effect, a different test is done with Duncan Test at the level of ap=0.05 (Gaspersz, 1991).

\section{RESULTS AND DISCUSSION}

\subsection{Results}

\subsubsection{Plant height $(\mathbf{c m})$}

Results of analysis of variance showed that the onion variety treatment of showed highly significant effect on the height meter onion plants aged 35 and 42 days after planting. Duncan test showed that the treatment of onion variety of significantly different from the onion treatment of Enrekang Local, Super Philip and Bauji variety. However, it is not significantly different from Tajuk varieties (Table 1).

Table.1: Average Plant Height (cm) Onion Age 35 and 42 Planting After Days (PAD) in the Treatment Various of Onion

Variety.

\begin{tabular}{|c|c|c|c|c|c|c|}
\hline \multirow{2}{*}{ Plant Height } & \multicolumn{5}{|c|}{ Various of Onion Variety (V) } & \multirow{2}{*}{ PAD } \\
\hline & $\mathrm{V}_{1}$ & $\mathrm{~V}_{2}$ & $\mathrm{~V}_{3}$ & $\mathrm{~V}_{4}$ & $\mathrm{~V}_{5}$ & \\
\hline \multirow{2}{*}{$\begin{array}{c}\text { Average } \\
\text { NP Duncan } \alpha=0.05\end{array}$} & $24.43 \mathrm{a}$ & $23.40 \mathrm{a}$ & $21.00 \mathrm{~b}$ & $20.27 \mathrm{a}$ & $21.42 \mathrm{~b}$ & \multirow{2}{*}{35} \\
\hline & 1.65 & 1.72 & 1.76 & 1.78 & & \\
\hline \multirow{2}{*}{$\begin{array}{c}\text { Average } \\
\text { NP Duncan } \alpha=0.05\end{array}$} & $32.41 \mathrm{a}$ & $29.70 \mathrm{~b}$ & $27.30 \mathrm{c}$ & $26.31 \mathrm{c}$ & $27.72 \mathrm{c}$ & \multirow{2}{*}{42} \\
\hline & 1.52 & 1.58 & 1.62 & 1.64 & & \\
\hline
\end{tabular}

Description: The same letters in the same row no significant effect on Duncan test level a $\mathrm{p}=0.05$

\subsubsection{Number of tubers (tubers)}

Results of analysis of variance showed treatment of various varieties of onion plants showed a significant influence on the number of tubers age 70 HST. Duncan's test showed that the treatment of Bima varieties was significantly different from Tajukvarieties, Enrekang
Local varieties, Super Philip varieties, and Bauji varieties. While the Tajuk varieties are significantly different from the Super Philip and Bauji varieties. However, it was not significantly different from the Enrekang Local varieties (Table 2).

Table.2: Average Number of Onion Tuber (cm) Onion Age 70 PAD in the Treatment Various of Onion Variety.

\begin{tabular}{cccccccc}
\hline \multirow{2}{*}{ Number of Tuber } & \multicolumn{5}{c}{ Various of Onion Variety $(\mathrm{V})$} & \multirow{2}{*}{ PAD } \\
\cline { 2 - 6 } & $\mathrm{v} 1$ & $\mathrm{v} 2$ & $\mathrm{v} 3$ & $\mathrm{v} 4$ & $\mathrm{v} 5$ & \multirow{2}{*}{70} \\
\hline Average & $8.11 \mathrm{a}$ & $7.04 \mathrm{~b}$ & $5.73 \mathrm{c}$ & $4.47 \mathrm{~d}$ & $6.50 \mathrm{~b}$ & \\
\cline { 2 - 7 } NP Duncan $\alpha=0.05$ & 0.534 & 0.555 & 0.568 & 0.577 & & \\
\hline
\end{tabular}

Description: The same letters in the same row no significant effect on Duncan test level a $\mathrm{p}=0.05$

\subsubsection{Production per hectare}

Results of analysis of variance showed that the treatment of onion variety various of plants showed a significant influence on the production per hectare at the age of 77 days HST. Duncan's test showed that Bima variety were significantly different from Enrekang Local, Super Philip, and Bauji variety. However, it is not significantly different from the treatment of Tajuk variety. While the variety of Tajuk is significantly different from the treatment of Super Philip and Bauji variety. However, it was not significantly different from the Enrekang Local variety

(Table

Table.3: Average Production per Hectare of Onion Age 77 PAD on Different Varietyof Onion

\begin{tabular}{|c|c|c|c|c|c|c|}
\hline \multirow{2}{*}{ Production per hectare } & \multicolumn{5}{|c|}{ Various of onionvariety (V) } & \multirow{2}{*}{ PAD } \\
\hline & $\mathrm{v}_{1}$ & $\mathrm{v}_{2}$ & $\mathrm{v}_{3}$ & $\mathrm{~V}_{4}$ & V5 & \\
\hline Average & $12.08 \mathrm{a}$ & $10.07 \mathrm{ab}$ & $7.30 \mathrm{c}$ & $6.14 c$ & $8.24 \mathrm{bc}$ & \\
\hline NP Duncan $\alpha=0.05$ & 2.077 & 2.160 & 2.211 & 2.243 & & \\
\hline
\end{tabular}

Description: The same letters in the same row no significant effect on Duncan test level a $\mathrm{p}=0.05$ 


\subsection{Discussion}

\subsubsection{Plant height}

The observation of high onion plants aged 35 and 42 dap real effect on the variety of plant onion. BimaBrebes variety of onion plants showed higher high of $32.41 \mathrm{~cm}$ while the lowest is $26.31 \mathrm{~cm}$ Bauji variety. This is due to the growing environmental condition factor matching onion variety of BimaBrebes compared with the treatment of other onion variety. According to Indah (2016), that improved variety of onion are expected variety adaptive high productivity, harvesting early maturing, resistant to pests and diseases, able to grow in the growth environment or agroekologi, and quality of tubers in accordance with the wishes of consumers.

\subsubsection{Number of Bulbs}

The observation of the number of bulbs of onion crop at the age of 70 real hstberpengaruh on different variety of onion crop. The BimaBrebes variety shows the highest number of onion tubers, namely 8.11 tubers, while the lowest is Bauji variety which is 4.47 tubers. This is due to factors of soil fertility conditions suitable with onion variety of BimaBrebes compared with the treatment of other onion variety. According to Asrijal et al. (2018), onions need fertile soil fertile and high in organic matter with the support of sandy clay or clay dust. The type of soil is good for growing onions is no Latosol soil, Regosol, grumosol, and Alluvial with a degree of acidity (pH) 5.5-6.5 soil and drainage and aeration in the soil goes well, the soil should not be inundated by water because can cause decay in tubers and trigger the emergence of various diseases (Sudirja, 2007).

According to Asrijal et al.(2018), a plant will grow and develop fertile if the nutrients provided can be absorbed by a plant and in the form needed. Napitupulu and Winarto (2009) stated that nutrients that are sufficient for onions can increase the weight of tuber crops. Onion plants can thrive and produce well, must be planted in a place that meets the growing environmental requirements including climate and soil fertility (Nasrullah, 2010).

\subsubsection{Production per hectare}

The observation of production per hectare of onions at the age of 77 days has a significant effect on various onion variety. The BimaBrebes variety shows that the highest yield per hectare of onions is 12.08 t.ha-1, while the lowest is Bauji variety which is 6.14 t.ha-1. This is due to genetic factors in the BimaBrebes variety of onions suitable for the environmental conditions of plant growth compared to other onion variety. According to Asrijal, et al., (2018), the growth and production of onions is influenced by the potential and quality of seeds or seeds sourced from various types of variety. Better production in Moujung and Sumenep variety, namely production of 6,34-8,0 2t.ha- ${ }^{-1}$. Variety that are tolerant of Fusarium wilt attacks are Moujung (attack rate is $1.84 \%$ ), while those tolerant to Alternaria are Moujung and Sumenep (attack rate of $9.60 \%-15.86 \%$ ) (Purbiati et al., 2010).

\section{CONCLUSIONS}

Onion adaptability is quite high in Wajo, onion variety that have high adaptability are the variety of BimaBrebes. Further research is needed to get maximum production by adding manure and the best growth regulator. The government is expected to support the achievement of onion production centers in Wajo.

\section{ACKNOWLEDGEMENT}

The authors are grateful to the Ministry of Research and Higher Education Indonesia for financial support through funding research DRPM-PDP 2018.

\section{REFERENCES}

[1] Asrijal, E. Syam'un, Y. Musa, dan M. Riadi (2018). Effect of Multiple of Plant Growth Regulator from Free Clean Maize to Growth and Production of Red Onion (Allium ascalonicumL.). Int.J. Curr. Microbiol. App. Sci.7(5):1824-1835

[2] BPS. (2015). Produksi cabai besar 1.075 juta ton, cabai rawit 0.8 juta ton, dan bawang merah 1.234 juta ton. Badan Pusat Statistik Republik Indonesia http://www.bps.go.id [29 Juni 2017].

[3] BPS. (2016). Kabupaten Wajo Dalam Angka. Badan Pusat Statistik, Sengkang.

[4] Damanik, M. M. B., B. E. Hasibuan, Fauzi, Sarifuddin, dan H. Hanum (2010). Kesuburan Tanah dan Pemupukan. Universitas Sumatera Utara. Medan.

[5] Fatmawaty, A.A., Sri Ritawati dan Lisa Noviyanti Said (2015). Pengaruh Pemotongan Umbi Dan Pemberian Beberapa Dosis Pupuk Npk Majemuk Terhadap Pertumbuhan Dan Hasil Tanaman Bawang Merah (Allium ascolanicum L.) Jurnal Agrologia, Vol. 4, No.2, Oktober 2015, Hal. 69-77

[6] Gaspersz (1991), Metode Perancangan Percobaan. Penerbit, CV. Armico, Bandung Indonesia.

[7] Indah, I.M. (2016). Keragaan Bawang Merah (Allium Ascalonicum L.) IPB Di Tiga Lokasi. Skripsi Departemen Agronomi Dan Hortikultura Fakultas Pertanian Institut Pertanian Bogor.

[8] Lingga, P dan Marsono (2013). Petunjuk Penggunaan Pupuk. Penebar Swadaya. Jakarta.

[9] Napitupulu, D dan L. Winarto (2009). Pengaruh Pemberian Pupuk N Dan K Terhadap Pertumbuhan Dan Produksi Bawang Merah. Balai 
Pengkajian Teknologi Pertanian Sumatera Utara.

J-Hort. 20 (1) : 22-35.

[10] Nasrullah (2010). Dampak Perubahan Iklim Terhadap Produksi Tanaman Pangan Di Sulawesi Selatan. Laporan Akhir Analisis Kebijakan. Makasar

[11] Purbiati T., A. Umar dan A Supriyanto (2010). Pengkajian Adaptasi Varietas Bawang Merah Toleran Hama Penyakit Pada Lahan Kering Di Kalimantan Barat. BPTP-Kalimantan Barat.

[12] Rahayu. S., Elfarisna dan Rosdiana (2016). Respon Pertumbuhan Dan Produksi Tanaman Bawang Merah (Allium ascalonicum L.)Dengan Penambahan Pupuk Organik Cair. Jurnal Agrosains dan Teknologi, 1(1):17

[13] Samad, S. (2008). Respon Pupuk Kandang Sapi dan KCL terhadap Pertumbuhan dan Produksi Bawang Merah (Alium ascalanicum L.), Buletin Penelitian. Lembaga Penelitian Universitas Has anuddin Makasar.

[14] Sinaga. I.M., E. S. Bayu, I. Nuriadi (2013). Adaptasi Beberapa Varietas Merah (Allium ascalonicum L.)Di Dataran Rendah Medan . Jurnal Online Agroekoteknologi 1(3):404-417

[15] Suwandi(2014). Budi Daya Bawang Merah di Luar Musim.IAARD Press. Jakarta. 